ks. Jan Górecki

\title{
Pielgrzymki do Piekar Śląskich w latach 1946-1947 w świetle okólników Kurii Diecezjalnej w Katowicach
}

\author{
Pilgrimages to Piekary Śląskie \\ in the years 1946-1947 in the light of circulars \\ of the Diocesan Curia in Katowice
}

\begin{abstract}
The article presents the history of male pilgrimages to the sanctuary in Piekary Śląskie in the years 1946-1947. The men's pilgrimage to Piekary Ślaskie is one of the most important and characteristic of this religious centre. Its origins date back to 1946. The author discusses the circulars issued by the Diocesan Curia in Katowice concerning the organization and conduct of these pilgrimages, and presents their socio-political context. He analyses the content of the watchwords accompanying pilgrimages in various years to recognize and fathom the meaning of the messages flowing from this place in the politically difficult times of Communist Rule. It highlights the integration and social role of pilgrimages to Piekary Śląskie, the care of Silesian bishops for the revival of the pilgrimage movement and the shaping of proper religious and social attitudes of the faithful.
\end{abstract}

Keywords: men's pilgrimages, Piekary Śląskie, sanctuary, Diocesan Curia in Katowice.

„Szczęśliwi biskupi i kapłani, którzy mają taki lud! Szczęśliwy lud, który ma takich biskupów i kapłanów" - te słowa wypowiedział na wzgórzu piekarskim jeden z zaproszonych gości, francuski kardynał Paul Joseph Marie Gouyon, widząc rzesze przybyłych tu pielgrzymów.

Sięgnijmy do powojennej historii pielgrzymek do Piekar, aby pokazać ich społeczno-polityczny kontekst. Należy się wczytać w treść haseł towarzyszących 
wszystkim pielgrzymkom, a następnie przypomnieć kontekst historyczny i polityczny w konkretnym roku. Trzeba sięgnąć do dorobku historyków, by zgłębić sens, zarówno hasła, jak i słów skierowanych do mężczyzn w przeddzień pielgrzymek, a także płynących z kalwaryjskiego wzgórza.

Niezależnie od sytuacji politycznej, gospodarczej czy społecznej tradycja pielgrzymowania „świata męskiego” do Piekar Śląskich trwa nieprzerwanie od 1947 r., a ściślej od września 1946 r. ${ }^{1}$.

Śląscy duszpasterze przygotowywali wiernych do pielgrzymowania do Piekar Śląskich już od 3 lipca 1945 r. Kuria Diecezjalna w Katowicach poprzez swój Referat Duszpasterski wydała z tą datą Okólnik III skierowany do księży proboszczów i wikarych. Jeden z obszerniejszych akapitów tego dokumentu zawiera ciekawe informacje związane z pielgrzymkami wiernych, ich terminarzem, organizacją i celami: „Nadszedł okres dorocznych pielgrzymek zahamowanych w ostatnich latach przez stosunki wojenne. Sekretariat Duszpasterski podaje w porozumieniu z Piekarami następujące dyrektywy praktyczne w tej materii. Przyzwyczajeni przed wojną do swobody religijnej, do manifestacyj i pielgrzymek, tym dotkliwiej odczuwaliśmy zupełne skrępowanie pod tym względem za czasów okupacji. Skoro dziś zapewniono nam znów swobodę religijną, korzystajmy z tego i w nadchodzącej porze urządzajmy jak najwspanialej długo oczekiwane pielgrzymki, by:

1. zadośćuczynić potrzebie ludu (żywy udział w procesjach Bożego Ciała dowiódł, $z$ jaką radością biorą wierni udział w religijnych manifestacjach);

2. wzmocnić tradycję przerwaną jedynie pod przymusem;

1 Z dokumentów Kurii Diecezjalnej w Katowicach wiadomo, że we wrześniu 1946 r., a więc ponad pół roku przed pierwszą oficjalną pielgrzymką stanową mężczyzn i młodzieńców do Piekar, przybyły do Matki Boskiej tysiące pielgrzymów. Wynika to z tekstu orędzia bp. Stanisława Adamskiego skierowanego do księży wszystkich parafii, datowanego na dzień św. Józefa 1947 r.: „Ukochani Diecezjanie! We wrześniu ub. r. odbyła się pierwsza powojenna pielgrzymka katolickich mężczyzn do Piekar Śląskich. U stóp Matki Boskiej Piekarskiej zebrały się tysiące mężów i młodzieńców. Zrozumieli, że kult mariański od wieków w Polsce rósł i rozwijał się potężnie nie tylko wśród dziatwy, niewiast i panien, ale gorzał także w sercach dorastającej młodzieży męskiej i dojrzałych mężczyzn. Cześć Maryi była od wieków serdecznym nabożeństwem żołnierza polskiego. Pod opieką Matki Najśw. ma świat podnieść się z ruin i pogorzelisk do nowego, lepszego i szczéśliwszego życia. Czci Maryi służą po parafiach naszych coraz to liczniejsze sodalicje mariańskie dorastającej młodzieży męskiej i mężczyzn dojrzałych. W tym też celu odbywać się będzie raz w roku, a to w pierwszą niedzielę maja, pielgrzymka wszystkich katolickich mężczyzn i młodzieńców do Piekar Śląskich". 
3. dać wiernym możność zżycia się i ściślejszego zespolenia się z własną parafią, jako też zetknięcia i zaznajomienia $z$ innymi parafiami na miejscu pielgrzymki; 4. dać wiernym okazję do odnowienia ducha przez przyjęcie sakramentów św., akty pokuty, zyskanie odpustów, które związane są z pielgrzymką.

Miejscem pielgrzymkowym dla nas to przede wszystkim Piekary, gdzie wypada nam podziękować za ocalenie cudownego miejsca Matki Boskiej i gdzie najlepiej dokonać uroczystego poświęcenia się Niepokalanemu Sercu Maryi poleconego nam przez samego Ojca św. Gdy powiaty rybnicki, cieszyński i raciborski wyleczą się coś niecoś ze skutków wojennych, wówczas niewątpliwie i Pszów stanie się celem licznych pielgrzymek" (Okólnik z 3 lipca 1945 r.).

Powyższe zapisy świadczą o wielkiej trosce kapłanów diecezji katowickiej o wiernych i ożywienie ruchu pielgrzymkowego. W wyniku II wojny światowej śląski Kościół został - podobnie jak cały kraj - okaleczony, zniszczony i upokorzony przez okupantów. Kościół to przede wszystkim wierni. Dlatego księża widzieli w ruchu pielgrzymkowym „lekarstwo” na uleczenie ducha katolików na Śląsku. Nie czekając na odbudowywanie świątyń, wyposażanie zakrystii, zaczynali od formowania człowieka najbardziej okaleczonego i sponiewieranego przez wojnę. Czytając kolejne akapity Okólnika z 3 lipca 1945 r., możemy się przekonać, jak trafnie księża ocenili sytuację na Śląsku, na jakie obszary zniszczenia duchowego zwracali uwagę, w jaki sposób wspierali wiernych, dawali im nadzieję w Bogu i ludziach, jak pomagali proboszczom i wikarym w pierwszych bardzo trudnych i skomplikowanych powojennych dniach i miesiącach, czynili pielgrzymkę wielkim świętem dla całej wspólnoty. Tekst zawiera ponadto wskazówki dla pielgrzymów dotyczące obowiązku przystąpienia do spowiedzi świętej, najlepiej w swoim kościele oraz wykorzystania czasu pobytu w miejscu pielgrzymkowym.

Okólnik radzi, aby nie zabierać ze sobą na pielgrzymkę obrazów ani figur ciężkich. Najlepiej zostawić je na granicy swojej parafii, a po powrocie uroczyście zanieść do swojego kościoła. W miejscu pielgrzymkowym nie należy rozpraszać się, ale brać wspólnie udział we wszystkich nabożeństwach. Ze względu na zniszczone drogi i brak środków lokomocji, najlepiej wyjść z domu grupą już w przeddzień święta. W drodze wstępować do mijanych kościołów, prosić, by dzwoniono na przyjście pielgrzymów dla podniesienia uroczystego nastroju. Zalecano, aby ksiądz szedł ze swoimi parafianami jako pielgrzym. Nie zapomniano także o kosztach, które miały być pokryte ze specjalnej kolekty niedzielnej urządzonej kilka tygodni przed planowaną pielgrzymką.

„Osobnych zezwoleń policyjnych lub innych na urządzenie pielgrzymki zasadniczo nie trzeba, chyba że istnieją wyjątkowo w danej parafii warunki, wobec których 
roztropność wskazywałaby na zgłoszenie pielgrzymki u władz lokalnych lub nawet na potrzebe prośby o pozwolenie" 2 .

Najciekawszy wydaje się ostatni zapis Okólnika: „Księża duszpasterze niechaj dbają o to, by pielgrzymki rzeczywiście zostały pielgrzymkami, a nie wyrodziły się w imprezy świeckie, nie dawały słusznych powodów do pośmiewiska, nie stały się źródłem wyzysku dla pewnych jednostek, słowem - by zachowano w nich godność aktu religijnego. Zachęcajmy do wzięcia udziału w nich - ludzie mają dziś wiele ciężkich kłopotów na sercu - pielgrzymka jest dobrą okazją, by je przedstawić Bogu Wszechmogącemu przez Matkę Najświętszą Pośredniczkę łask".

Nader aktualne wydaje się to przesłanie z lipca 1945 r. pod adresem dzisiejszych pielgrzymów, zdążających nie tylko do Piekar Śląskich, podpisane przez ks. Bolesława Kominka - wielkiego syna Ziemi Radlińskiej.

Kolejnym okólnikiem, który w części był poświęcony sprawie pielgrzymki do Piekar, był Okólnik z 16 stycznia 1947 r., podpisany już przez ks. Herberta Bednorza. Czytamy w nim: „Przypominamy, że w niedzielę 4 maja br. jest przewidziana pielgrzymka mężów i młodzieńców całej diecezji do Piekar Śląskich. Już teraz o tym piszemy, aby wszyscy księża często o tym w naszych organizacjach kościelnych np. sodalicjach mariańskich młodzieńców i mężów, mówili" (Okólnik nr 1 z 16 stycznia 1947 r.).

Dnia 15 lutego 1947 r. w Okólniku nr 2 ks. Herbert Bednorz znów napisał: „Przypominamy na nowo, że w pierwszą niedzielę maja odbędzie się pierwsza powojenna pielgrzymka mężów i młodzieńców katolickich do Piekar Śl. Na pewno mówiliśmy o tym w sodalicjach mariańskich mężów i młodzieńców. Warto także o tym wspomnieć w innych organizacjach męskich, nie odgradzających się od myśli katolickiej, jak np. w harcerstwie, związku więźniów politycznych, u weteranów powstań śląskich itd. Zachęcimy mężów i młodzieńców, by jak najliczniej wybrali się do Piekar Śl. Pielgrzymka będzie miała jako hasło naczelne: "Przez trzeźwość mężów i młodzieńców do trzeźwości narodu"."

Po lekturze tego tekstu nasuwają się następujące wnioski:

- biskupowi katowickiemu bardzo zależało na jak najliczniejszym udziale mężczyzn w pielgrzymce do Piekar;

2 Z tego zapisu można wnioskować, że władza jeszcze wtedy nie zabraniała i nie utrudniała wiernym organizacji pielgrzymek, co wynikało z nadmiaru innych problemów, z jakimi borykała się w pierwszych powojennych miesiącach. Okólnik z 3 lipca 1945 r. 
- już w 1947 r. miejscowy ordynariusz chciał uczynić z pielgrzymki do Piekar spotkanie wielu różnych środowisk męskich u tronu Matki Boskiej Piekarskiej;

- ordynariusz katowicki planował zająć się w Piekarach problemem nadużywania alkoholu przez ludzi nie tylko zamieszkujących Górny Śląsk, ale takżej z całej Polski (pierwsze lata powojenne sprzyjały nadużywaniu alkoholu, w tym własnej produkcji).

Dnia 15 marca 1947 r. w Okólniku nr 3 ks. Herbert Bednorz po raz kolejny przypomniał o czekającym diecezję wydarzeniu: „Dwie niedziele przedtem, a więc 20 kwietnia, należy z ambon odczytać krótką odezwę J.E. Ks. Ordynariusza, w której zachęci cały katolicki świat męski do udziału w pielgrzymce. Odezwa zostanie na czas przysłana. W czasie pielgrzymki przypomną sobie nasi mężczyźni treść zeszłorocznych ślubów maryjnych oraz uświadomią sobie szczególne hasło pielgrzymkowe: "Przez trzeźwość mężów i młodzieńców do utrzeźwienia narodu". Z Piekar Śl. promieniowało często na cały Śląsk hasło wstrzemięźliwości i umiarkowania w używaniu trunków alkoholowych. Oby i przy tej stanowej pielgrzymce katolickich mężczyzn tak było.

Projektowane są pociągi popularne: Wodzisław-Piekary, Mikołów-Piekary, Cieszyn-Piekary. Zachęcajmy wszyskich mężczyzn naszych parafii do udziału w tej pielgrzymce! Dalsze komunikaty, odnoszące się do pielgrzymki mężczyzn do Piekar Śl., prześlemy w następnym okólniku”.

Z powyższych treści wynika, że bp ordynariusz Stanisław Adamski znał historię i szeroki zasięg ruchu trzeźwościowego zapoczątkowanego jeszcze w XIX w. przez ks. Jana Alojzego Nepomucena Fietzka w Piekarach (Górecki 2011). Zapis sugeruje także, z których części województwa należało spodziewać się największej liczby pielgrzymów. Można domniemywać, że zainteresowanie przyjazdem do Piekar było dość znaczące z kierunku południowego i południowo-zachodniego województwa śląskiego.

Na trzy tygodnie przed pielgrzymką, 12 kwietnia 1947 r., prawie cały Okólnik $n r 4$, podpisany przez ks. Herberta Bednorza, był jej poświęcony. Duszpasterzom przypominano, że jest to największe wydarzenie duszpasterskie na terenie diecezji w okresie wiosennym. Drugie zdanie mówi o dołożeniu wszelkich starań, aby to przedsięwzięcie religijne się udało. Potrzebna jest do tego gorąca modlitwa.

Biskup ordynariusz poprzez ks. Bednorza nadał wielką rangę i znaczenie pielgrzymce. „Chodzi o wielką sprawę Bożą (...) o ożywienie naszego duszpasterstwa na odcinku ogromnie ważnym, tj. wśród mężów i młodzieńców. Jest to jednym z głównych celów tej pielgrzymki (Okólnik nr 4 z 12 kwietnia 1947 r.). 
Zadbano o wszystkie szczegóły organizacyjne. Podano rozkład jazdy pociągów z Cieszyna, Wodzisławia, Nowego Bierunia i Mikołowa. Rozpisano wszystkie stacje, na których pociągi będą się zatrzymywały. Wymieniono m.in.: Bielsko, Dziedzice, Janów, Katowice-Ligotę, Pszczynę, Orzesze, Rybnik, Skoczów. W okólniku tym mamy także dokładne informacje o kosztach przejazdu. Najdroższy był bilet z Cieszyna, który kosztował 240 złotych. Najtańszy z Mikołowa do Katowic 80 złotych. W uwagach końcowych okólnika jest informacja, że do 4-5 maja ceny biletów mogą wzrosnąć. Przy tej okazji przypomniano wiernym o zmianie czasu z zimowego na letni w nocy z 3 na 4 maja. Wyjazd pociągami miał charakter grupowy i był organizowany przez Referat Duszpasterski za pośrednictwem parafii (Okólnik nr 4 z 12 kwietnia 1947 r.).

Pomyślano też o pielgrzymach udających się do Piekar Śląskich samochodami ciężarowymi. Zasugerowano, aby pojazdy zmechanizowane zorganizować w porozumieniu z dyrekcjami hut, kopalń czy fabryk. Wydaje się, że do 12 kwietnia $1947 \mathrm{r}$. władze kurii katowickiej nie widziały żadnych prób nacisku ze strony rządzących na kierujących zakładami pracy, aby ci w jakiś sposób utrudniali organizacje pielgrzymek. Dyrekcje tych zakładów pracy były raczej przychylnie nastawione do pomocy w przygotowaniu aut ciężarowych.

Ks. Herbert Bednorz w przywołanym okólniku zachęcał mężczyzn do zabrania ze sobą sztandarów, poproszenia o oprawę muzyczną w postaci towarzyszących pielgrzymom orkiestr, ubrania się w stroje regionalne. Na czele procesji parafialnej do Piekar powinny być niesione krzyż i tablica z nazwą parafii. Mile widziane miały być transparenty z napisami religijnymi. Proszono parafian, aby w niedzielę 4 maja nie urządzali uroczystości lokalnych, np. święto św. Floriana zaproponowano uczcić 10 maja.

Prawie całą stronę powyższego okólnika poświęcono szczegółowemu programowi pielgrzymki. Przyjęte wówczas jego ramy do tej pory nie uległy zasadniczej zmianie. Na sobote 3 maja zaplanowano o godzinie 15.00 nieszpory przed cudownym obrazem Matki Bożej Piekarskiej, potem obchody z kazaniami stanowymi na kalwarii. Na godzinę 19.00 pielgrzymów zaproszono na nabożeństwo majowe odprawiane przed cudownym obrazem. Zachęcano też do skorzystania z sakramentu pokuty.

W niedziele 4 maja 1947 r. program przedstawiał się następująco:

(...) godzina 5-ta Godzinki do Najświętszej Maryi Panny w kościele Matki Boskiej oraz sposobność do Komunii św. na Rajskim Placu.

Godz. 6-ta odsłonięcie obrazu, msza św., krótkie kazanie. 
Godz. 7-ma wymarsz na dalszy ciąg obchodów z kazaniami stanowymi dla mężczyzn.

Godz. 10-ta przywitanie Najdostojniejszych Arcypasterzy przed kościołem Matki Boskiej, formowanie procesji na górę kalwaryjska. Po drodze śpiewamy: Tysiąc razy pozdrawiamy Ciebie, Gwiazdo śliczna, wspaniała ...

Godz. 10.30 przywitanie pielgrzymów -Ks. Prob. Ligoń, suma pontyfikalnaJ.E. Najprz. Ks. Bp Adamski, kazanie-J.E. Ks. Administrator Apostolski Dr. Milik, w czasie mszy św. śpiewamy: Chwalcie łąki umajone, Pod Twój płaszcz się uciekamy, Z tej biednej ziemi. Wspólnie odmawiamy: Wierzę w Boga, Ojcze nasz. Po błogosławieństwie śpiewamy: My chcemy Boga. Po kazaniu - odnowienie ślubów jasnogórskich.

Godz. 12-ta do 13.30 - przerwa obiadowa.

Godz. 13.30 obrady mężów i młodzieńców osobno. Mężowie zbierają się w ogrójcu, młodzieńcy przy wieczerniku.

Godz. 15-ta nabożeństwo majowe na szczycie kalwaryjskim - J.E. Najprzew. Ks. Bp Bieniek, krótkie kazanie - Najprzew. Ks. Admin. Apost. Dr Kominek - Boże, coś Polskę - procesja powrotna do kościoła parafialnego, wyjazd do domu (Okólnik nr 4 z 12 kwietnia 1947 r.).

Najwięcej ciekawych informacji związanych z genezą piekarskich pielgrzymek stanowych mężczyzn i młodzieńców do Piekar Śląskich znajdujemy w orędziu bpa Stanisława Adamskiego, przeczytanym z ambon w niedzielę 20 kwietnia $1947 \mathrm{roku}^{3}$.

Orędzie nawiązuje do - mającej miejsce rok wcześniej - wrześniowej pielgrzymki do Piekar, która liczyła tysiące mężów i młodzieńców. Bp stwierdza, że „świat męski" zrozumiał znaczenie kultu maryjnego w Polsce, który trwa od wieków. Rozwijał się nie tylko wśród dziatwy, niewiast i panien, ale także w sercach dorastającej młodzieży męskiej i dojrzałych mężczyzn. „Cześć Maryi była od wieków serdecznym nabożeństwem żołnierza polskiego. Pod opieką Matki Najświętszej ma świat podnieść się z ruin i pogorzelisk do nowego, lepszego i szczęśliwszego życia. Czci Maryi służą po parafiach naszych coraz to liczniejsze sodalicje mariańskie dorastającej młodzieży męskiej i mężczyzn dojrzałych".

3 Orędzie zostało napisane 19 marca 1947 r., w dniu św. Józefa, i podpisane przez bp. katowickiego Stanisława Adamskiego, z zaleceniem przeczytania go z ambon w niedzielę 20 kwietnia po kazaniu. Orędzie biskupa S. Adamskiego z 19 marca 1947 r. 
Dalej ks. biskup wyznacza pierwszą niedzielę maja jako datę pielgrzymki męskiej do Piekar. Następnie zwraca uwagę wiernym, że w wyjątkowych czasach należy gorąco czcić Najświętszą Maryję Pannę. Jako dowód na to, że Matka Boska służy pomocą ludziom w przełomowych, trudnych okresach historycznych, podane są Jej objawienia w Fatimie pod koniec I wojny światowej. Także Ojciec Święty Pius XII wczasach II wojny światowej wezwał wiernych do odmawiania różańca świętego w rodzinach i poświęcił rodzaj ludzki Niepokalanemu Sercu Maryi. Tak też uczynili wszyscy biskupi świata katolickiego. W sierpniu $1946 \mathrm{r}$. w Piekarach Śląskich, już po polsku, w święto Wniebowzięcia Matki Boskiej, dokonano poświęcenia Niepokalanemu Sercu Maryi całej diecezji. We wrześniu tegoż roku w dzień Narodzenia Najświętszej Maryi Panny Episkopat Polski na Jasnej Górze poświęcił cały naród polski Maryi. Tekst tego ślubowania brzmiał: „Tobie i Twojemu Niepokalanemu Sercu poświęcamy siebie, Naród cały i wskrzeszoną Rzeczpospolitą, obiecując Ci wierną służbę, oddanie zupełne oraz cześć dla Twych świątyń i ołtarzy. Synowi Twojemu a naszemu Odkupicielowi ślubujemy dochowanie wierności Jego nauce i prawom, obronę Ewangelii i Kościoła, szerzenie Jego Królestwa"4.

Należy zauważyć, że akt poświęcenia diecezji katowickiej Sercu Maryi miał miejsce miesiąc przed poświęceniem jasnogórskim. Świadczy to o „zapobiegliwości" ordynariusza katowickiego w działaniu na rzecz odnowy duchowej i dawania nadziei swoim diecezjanom rok po ustaniu działań wojennych.

Bp w orędziu kilka razy nawiązuje do ślubowania z 1946 r., zapowiadając jego odnowienie i przypomnienie jego znaczenia po to, aby latwiej i skuteczniej wykonać je w życiu. Mężczyznom wyznaczony został konkretny cel przybycia do Piekar 4 maja 1947 r. Sformułowano także hasło: Przez trzeźwość mężów i młodzieńców do utrzeźwienia narodu polskiego. Bp w tym miejscu orędzia wyjaśnił, że wybrane hasło będzie przybliżone w obradach popołudniowych, oddzielnych dla młodzieńców i mężczyzn dojrzałych. W dalszej części orędzia wierzący usłyszeli wiele słów zachęcających ich do poniesienia trudu pielgrzymowania. Ordynariusz zwracał szczególną uwagę na wielką siłę sakramentów świętych, wspólnej modlitwy, wspólnego śpiewania. „Na tych nabożeństwach uświadamiacie sobie potęgę, moc i znaczenie katolicyzmu dla świata męskiego" (Orędzie z 19 marca 1947 r.: 2).

4 Jest to kolejny fragment cytowanego orędzia, patrz przypis 1 . 
Bp Stanisław Adamski podkreśla również olbrzymią rolę mężczyzn w rodzinie: „(...) już jesteście lub będziecie głowami rodziny, odpowiedzialnymi nie tylko za jej powstanie i wyżywienie, ale i za jej kierunek i życie z Bogiem (...) Za Waszym przykładem i w tej samej intencji będą pielgrzymowały do Panienki Piekarskiej inne stany: Wasze matki, żony, córki, nawet dzieci. Wasze! (...) Wy pójdziecie pierwsi. Dajcie członkom rodzin Waszych przykład dobry i zachętę" (Orędzie z 19 marca 1947 r.). Tu następuje cytat z listu prymasa Polski kard. Augusta Hlonda, którego bp Adamski nazywa pierwszym biskupem śląskim: „Piekary to żywa krynica, z której z woli Bożej Matka Najśw. na Śląsk cały strumieniami rozlewa przeróżne łaski ku ukojeniu serc" (Hlond 1926: 3). Autor orędzia, wzmacniając swoje słowa do wiernych, przytacza również bardziej znany cytat kard. Hlonda związany z Piekarami: „Ludu Śląski! Ktokolwiek dochodzi przyczyn Twej głębokiej wiary, musi pójść do Piekar (...) Tylko ten pojmie Twoją wiarę zupełnie, kto cię widział przed cudownym obrazem" (Hlond 1926: 3).

W orędziu znajdują się też słowa skierowane do kapłanów, aby w miarę możliwości, o ile im na to pozwolą niedzielne obowiązki duszpasterskie, także przybyli do Piekar.

Na zakończenie bp Adamski pisze: „Niech z każdej parafii, z najmniejszej i najodleglejszej wybierze się silna delegacja mężów i młodzieńców. Przybądźcie koleją, autami i powózkami. Przybywajcie także pieszo! Trudności i kłopoty związane z pielgrzymką ofiarujemy Bogu w duchu pokuty za winy nasze. Do tego nawołuje Najśw. Panna i Kościół! Duszpasterze Wasi niech Was przed tym wyspowiadają, abyście z duszą czystą stanęli u stóp Niepokalanej" (Orędzie z 19 marca 1947 r.).

Dwustronicowe orędzie ordynariusza diecezji katowickiej zostało bardzo głęboko przemyślane pod względem treści i formy, a także adresatów. Nie chciano pominąć nikogo, chciano, aby pielgrzymka była jak najliczniejsza, dobrze przygotowana. A najważniejsze, żeby była wielkim przeżyciem duchowym, żeby dodawała mężczyznom i młodzieńcom dużo siły duchowej w pracy i w rodzinie. Jednym słowem, miała być początkiem ich Bożego formowania u Matki Boskiej Piekarskiej. Nikt pewnie nie przewidział, że jej tradycja przetrwa do dzisiaj. Wydaje się jednak, że duchowieństwo katowickie pod przewodnictwem bp. Adamskiego już snuło plany na przyszłość i modliło się o rozwój i przetrwanie ruchu pielgrzymkowego do Piekarskiej Pani.

Świadczy o tym chociażby Komunikat Kurii Diecezjalnej w Katowicach z 22 kwietnia 1947 r. w sprawie pielgrzymki mężów i młodzieńców do Piekar 
w niedzielę 4 maja, podpisany przez ks. dr. Herberta Bednorza ${ }^{5}$. Znajdujemy w nim kilka ważnych i dość symptomatycznych na przyszłość uwag technicznych i informacyjnych dotyczących pielgrzymki. „W ostatniej chwili Ministerstwo Komunikacji odwołało przyrzeczone przedtym pociągi specjalne do Piekar. Wobec tego musimy tym więcej dołożyć starań, by wszelkimi innymi sposobami tam się dostać, wiemy, że w zeszłym roku do Częstochowy także nie było dodatkowych pociągów, a jednak zebrały się tam tak wielkie rzesze, jakich Polska jeszcze nie widziała. Naśladujmy ten przykład! Jedźmy do Piekar pociągami normalnymi, autobusami, ciężarówkami, wozami, idźmy pieszo!" (Komunikat Kurii Diecezjalnej w Katowicach z 22 kwietnia 1947 r.: 1).

Komunikat przypomina także o zmianie rozkładu jazdy i przesunięciu godziny ze względu na wprowadzenie czasu letniego. Kuria w komunikacie poinformowała o przyrzeczeniu PKS, która zobowiązała się uruchomić 4 maja „szereg autobusów z Katowic do Piekar (przez Bytom) między godziną 7.00 a 9.30 rano. Wyjazd co kwadrans z Placu Zamkowego. Z treści komunikatu wynika, że kuria była poinformowana o szczególnej - ze względu na inicjatorów i skład - pielgrzymce z Katowic. Z Katowic wyrusza piesza pielgrzymka o godzinie 6-tej z Placu zamkowego i pójdzie trasą: Dąb-Chorzów-Bytom-Piekary. Po drodze dołączą się grupy z okolicznych parafii. Inicjatywy do tej pielgrzymki pieszej dała grupa byłych żołnierzy frontowych, powstańców i jeńców. Grupa ta wzywa wszystkich byłych żołnierzy spod Monte Cassino, Tobruku, Narwiku, Lenino, itd. wszystkich jeńców obozów koncentracyjnych i wojennych do gremialnego udziału w tej pielgrzymce. Trzeba mężom i młodzieńcom zwrócić uwagę na to, że pielgrzymka każda winna być połączona z pewną ofiarą. Wielu ślubowało w czasie wojny pielgrzymkę pieszą. Jest okazja do wykonania tego ślubowania" (Komunikat Kurii Diecezjalnej w Katowicach z 22 kwietnia 1947 r.: 1).

Biskup katowicki bardzo dobrze orientował się w sytuacji społecznej społeczeństwa śląskiego. Wiedział, że na terenie diecezji żyją byli powstańcy, żołnierze walczący o Polskę zarówno na wschodzie, jak i na zachodzie, jeńcy obozów koncentracyjnych. Im należało się duchowe wsparcie najbardziej i jak najszybciej, oni potrzebowali zaczerpnięcia ducha nadziei w Piekarach.

Komunikat zawierał wskazówki, gdzie należy wieszać afisze zapraszające pielgrzymów do Piekar: nie tylko na drzwiach kościelnych, ale i w składach

5 Tekst tego komunikatu pochodzi $z$ archiwum własnego autora. Widnieje na nim podpis z tytułem naukowym ks. H. Bednorza. 
i w innych miejscach publicznych. Dalej czytamy: „Prosimy Księży Proboszczów, aby do Pielgrzymki zaprosili także świeckie organizacje męskie i młodzieżowe stojące na gruncie zasad katolickich, jak np.: Harcerstwo, Związek Weteranów Powstań Śląskich, Związek b. Więźniów Politycznych, Samopomoc Chłopską, itd. Nie zawadzi zwrócić się z piśmiennym zaproszeniem, zachęcającym do udziału w pielgrzymce do załóg naszych fabryk, hut i kopalń. Poślijmy do ich gablotki propagandowej przynajmniej jeden lub dwa afisze propagandowe" (Komunikat Kurii Diecezjalnej w Katowicach z 22 kwietnia 1947 r.). Na zakończenie napisano: „Módlmy się o piękną pogodę i o to, by pielgrzymka ta stała się źródłem ożywienia całego naszego duszpasterstwa stanowego wśród młodzieży i mężów" (Komunikat Kurii Diecezjalnej w Katowicach z 22 kwietnia 1947 r.).

Już 7 maja 1947 r. kuria skierowała do księży proboszczów, wikarych i prefektów diecezji katowickiej kolejny okólnik (Okólnik z 7 maja 1947 r.), w którym w punkcie pierwszym znalazło się podsumowanie pielgrzymki do Piekar zatytułowane Pokłosie pielgrzymki mężów i młodzieńców do Piekar: „Wiele by można napisać o wrażeniach z pielgrzymki stanowej naszego katolickiego świata męskiego. Jedno wrażenie dominuje ponad wszystkimi innymi: 4 maja br. byliśmy w Piekarach świadkami potęgi naszego katolicyzmu męskiego. Na jedno wezwanie naszego Arcypasterza zebrało się około 100.000 mężów i młodzieńców u stóp Panienki Piekarskiej. Bóg zapłać Konfratrom, którzy zachęta i pracą swoją przyczynili się do tego, że tak wielu przybyło pielgrzymów do Piekar. W największym skupieniu uczestniczyli oni we mszy św., słuchali kazań, brali udział w godzinie stanowej i nabożeństwie majowym. Niezapomniany to był widok, zobaczyć tylu mężów i młodzieńców, wśród nich wielu z akademickim wykształceniem, rozśpiewanych i rozmodlonych. Na godzinie stanowej dla mężów wybuchł spontaniczny entuzjazm, zebrani mężowie oklaskami przerywali kazanie J.E. Ks. Biskupa Sufragana. Powiedzmy o tym wszystkim mężom i młodzieńcom naszej parafii i zapowiedzmy podobną pielgrzymkę za rok. Cała pielgrzymka dowiodła, że mężczyźni nasi są głęboko przywiązani do wiary św. O tym będziemy pamiętali w naszej pracy duszpasterskiej. Dlatego więcej niż dotąd będziemy zwracali uwagę na duszpasterską opiekę mężczyzn, czy to w ramach regularnych nabożeństw stanowych, odbywanych raz na miesiąc, czy to w ramach sodalicji młodzieży męskiej i mężczyzn dojrzałych. Najłatwiej będzie można duszpasterską opiekę mężów i młodzieńców podnieść w okresie komunijnym. Nie zaniedbując opieki religijnej nad rodzajem żeńskim, zwrócimy większą uwagę na duszpasterską 
opiekę naszych mężczyzn" (Komunikat Kurii Diecezjalnej w Katowicach z 22 kwietnia 1947 r.).

Treść tego podsumowania ze strony kurii wydaje się bardzo umiarkowana, skromna w ocenie. Zawiera natomiast wiele uwag skierowanych pod adresem księży, dotyczących dalszej rzetelnej pracy duszpasterskiej dla wiernych, zwłaszcza mężczyzn. Widać tu wielką pokorę biskupa i jego współpracowników wobec tajemnicy wiary i pobożności śląskich mężów i młodzieńców, widocznej w Piekarach Śląskich w 1947 r. Zapisy tego okólnika przekonują nas, że pielgrzymowanie jest wielką tajemnicą. Darem Boga dla ludzi. Zadaniem duchownych jest ten dar pielęgnować, dbać o jego duchowy charakter, w taki sposób, aby był trwały i silny, zdolny do przetrwania niezależnie od sytuacji zewnętrznej. A przede wszystkim przekazywany z pokolenia na pokolenie.

Mszę św. w 1947 r. na piekarskim wzgórzu odprawił bp Stanisław Adamski, a homilię wygłosił pochodzący z Radlina administrator apostolski w Opolu ks. Bolesław Kominek. Powiedział wtedy m.in: „(...) wszystkie reformy na Śląsku wyszły z Piekar i sięgały nawet poza obręb Śląska" (Górecki 2005: 36). Słowa homilii ks. B. Kominka okazały się praktyczne, a dla rządzących niepokojące. Przekonaliśmy się o tym w następnych latach. Mężczyźni nieprzerwanie pielgrzymowali do Piekar. Duchowieństwo z nimi. Coraz lepiej zorganizowani, w coraz większych grupach, coraz lepiej wykształceni i coraz bardziej przekonani o tym, że tak trzeba, zwłaszcza w okresach największego totalitaryzmu.

Władza komunistyczna zawsze z pewnymi obawami i niepokojem przygotowywała się do tych majowych spotkań na kalwaryskim wzgórzu. Organizatorzy również, ponieważ nigdy nie byli w stanie przewidzieć, jakie konkretne działania podejmie reżim, aby utrudnić pielgrzymom drogę i pobyt w Piekarach. Wszystko musiało być przygotowane perfekcyjnie z jednej i drugiej strony. Strona kościelna musiała robić wszystko, aby nie dać się sprowokować, a władza świecka też wszystko, aby ograniczyć na przyszłość zasięg i wielkość pielgrzymek. Służba Bezpieczeństwa zajmowała wszystkie najlepsze miejsca obserwacyjne, dysponowała nowoczesnymi narzędziami rejestracyjnymi, a jej funckcjonariusze często "mieszali się" z tłumem, udając pielgrzymów. Wysiłki i wszelkie starania władzy, których celem było przeciwdziałanie ruchowi pielgrzymkowemu, były nieskuteczne. Na nic się zdała np. likwidacja stacji kolei pasażerskiej w Piekarach, likwidacja linii tramwajowej, organizowanie w niedzielę pielgrzymkową atrakcyjnych imprez sportowych, darmowych wycieczek zakładowych czy emitowanie zagranicznych 
filmów w telewizji, legitymowanie i zatrzymywanie zdążających do Piekar pielgrzymów, wyłączanie prądu.

Do Piekar się szło, żeby zamanifestować swoją niezależność i autonomię duchową, podkreślić swoje przywiązanie do tradycji i wiary przodków, żeby pokazać władzy, z kim można rozmawiać szczerze i otwarcie o ważnych sprawach religijnych i problemach społecznych. A było o czym rozmawiać, szukać nadziei, otrzymywać wskazówki na życie w trudnych, często absurdalnych codziennych sytuacjach. To, co niepokoiło mężczyzn, co ich smuciło, denerwowało, to m.in. eliminowanie nauki religii z placówek oświatowych, czterobrygadowy system pracy w górnictwie, utrudnienia w budowaniu nowych kościołów, laicyzacja życia, brak szacunku dla człowieka ciężko pracującego, ograniczanie wolności słowa. W czasach postkomunistycznych zaś: nierówność społeczna, bezrobocie, kryzys rodziny, pogoń za pieniądzem, problemy etyczne w pracy, „szara strefa”, emigracja zarobkowa, rozbicie rodzin. Animatorzy pielgrzymek, biskupi katowiccy za każdym razem spełniali oczekiwania przybywających mężczyzn, mówiąc do nich z kalwaryjskiego wzgórza tak, aby dać im nadzieję, pokazać, że problemy ludzi pracy są im znane i bliskie. Z treści i klimatu homilii można było odczytać empatię duszpasterzy, tę ludzką, jak i religijną: „Niedziela jest Boża i nasza, Niedziela należy do was, Wszystkim robotnikom trzeba także godziwego odpoczynku w niedziele i święta (...) do tego robotnik ma niezaprzeczalne prawo"6.

Nie wiadomo, kto był autorem riposty skierowanej do władzy komunistycznej: „[Idziemy] Panu Bogu na chwałę, a tym pieronom na złość”7. Trzeba jednak stwierdzić, że oddaje ona i charakter i klimat tamtych czasów. Pokazuje w jednym, krótkim zdaniu, że Górnoślązaków ani nie jest łatwo przestraszyć, ani zniechęcić, ani pozbawić wartości przekazywanych z pokolenia na pokolenie. Można je zapisać tak: „Modlić się, pracować i starszych szanować”. I oby tak zostało na Śląsku!

Taki to początek miały doroczne pielgrzymki mężczyzn i młodzieńców. Z biegiem lat przybierały coraz doskonalszą formę, która wciąż się moduluje, ale wszystko na większą chwałę Boga i ludzi Śląska, a nawet całego kraju.

6 Wszystkie cytaty pochodzą z homilii wygłaszanych podczas pielgrzymek męskich do Piekar.

7 „Gość Piekarski”, 2007 [z 27 V], s. 9.

8 Słowa piosenki Stanisława Sojki, które oddają filozofię codziennego życia Ślązaka. 


\section{Literatura}

\section{Dokumenty}

Komunikat Kurii Diecezjalnej w Katowicach z 22 kwietnia 1947 r.

Okólnik III z 3 lipca 1945 r. wydany przez Kurię Diecezjalną w Katowicach.

Okólnik nr 1 z 16 stycznia 1947 r. wydany przez Kurię Diecezjalną w Katowicach Referat Duszpasterski.

Okólnik nr 2 z 15 lutego 1947 r. wydany przez Kurię Diecezjalną w Katowicach Referat Duszpasterski.

Okólnik nr 3 z 15 marca 1947 r. wydany przez Kurię Diecezjalną w Katowicach Referat Duszpasterski.

Okólnik nr 4 z 12 kwietnia 1947 r. wydany przez Kurię Diecezjalną w Katowicach Referat Duszpasterski.

Okólnik nr 5 z 7 maja 1947 r., wydany przez Kurię Diecezjalną w Katowicach.

Orędzie biskupa S. Adamskiego z 19 marca 1947 r.

\section{Opracowania}

„Gość Piekarski”, 2007 [z 27 V], s. 9.

Górecki J., 2005, Pielgrzymowanie do Piekar Ślaskich w XIX i XX wieku, „Studia Piekarskie", nr 1, s. 23-58.

Górecki J., 2011, Sanktuarium Matki Sprawiedliwości i Miłości Społecznej w Piekarach Ślaskich. Studium historyczno-pastoralne, Studio Noa, Katowice, Rybnik. Hlond A. kard., 1926, Orędzie w sprawie koronacji obrazu Matki Boskiej Piekarskiej, [w:] Pamiątka koronacji Cudownego Obrazu Matki Boskiej Piekarskiej. Piekary, s. 3-4.

ks. Jan Górecki, prof. dr hab.

Wydziat Teologiczny

Uniwersytet Śląki w Katowicach 